\title{
McCune-Albright Syndrome with Hypophosphatemic Rickets
}

\author{
Manish Gutch, ${ }^{\text {S }}$ ukriti Kumar, ${ }^{2}$ Keshav Kumar Gupta, ${ }^{1}$ Abhinav Kumar Gupta, ${ }^{1}$ Syed Mohd Razi ${ }^{1}$ \\ ${ }^{1}$ Department of Endocrinology, Lala Lajpat Rai Memorial Medical College, Meerut, India \\ ${ }^{2}$ Department of Radiodiagnosis, Sanjay Gandhi Post Graduate Institute of Medical Sciences, Lucknow, India
}

\begin{abstract}
Fibrous dysplasia (FD) is sometimes accompanied by extraskeletal manifestations that can include any combination of café-au-lait macules, hyperfunctioning endocrinopathies, such as gonadotropin-independent precocious puberty, hyperthyroidism, growth hormone excess, FGF23-mediated renal phosphate wasting, and/or Cushing's syndrome, as well as other less common features. The combination of any of these findings, with or without FD, is known as McCuneAlbright syndrome (MAS). The broad spectrum of involved tissues and the unpredictable combination of findings is because of a molecular defect due to dominant activating mutations in the widely expressed signalling protein Gsa. These mutations arise sporadically, often early in development, prior to gastrulation and can distribute across many or few tissues. ${ }^{1,2}$
\end{abstract}

We present a case of a 31/2 year-old-girl who presented simultaneously with precocious puberty and hypophosphatemic rickets, along with fibrous dysplasia and café-au-lait macules.

Key words: McCune-Albright syndrome, fibrous dysplasia, precocious puberty, café-au-lait macules, hypophosphatemic rickets

\section{INTRODUCTION}

McCune-Albright Syndrome is a rare, heterogenous disorder caused by a sporadic, somatic, post-zygotic mutation in GNAS. It is most commonly manifested as the triad of polyostotic fibrous dysplasia, café-au-lait hyperpigmentation along with hyperfunctional endocrinopathies. ${ }^{2,3}$ The syndrome has a female predilection $^{1}$ with an estimated prevalence between $1 / 100,000$ and $1 / 1,000,000 .{ }^{4}$ The most easily visually assessed feature is café-au-lait skin pigmentation characterized by hyperpigmented maculae with pathognonomic irregular and serpinginous borders classically described as the "Coast of Maine," which are mainly found on the anterior and posterior neck, gluteal region, thorax, back, shoulder and pelvis. ${ }^{2}$ The most common feature of the syndrome, fibrous dysplasia (FD) which can be monoostotic (single bone involvement) or polyostotic (multiple bone involvement) is characterized by the replacement of medullary bone with a poorly organized fibrous tissue containing trabeculae of immature bone. ${ }^{2,6}$ The third component of the classical triad is hyperfunctioning endocrinopathies which may include precocious puberty, hyperthyroidism, pituitary adenomas, primary adrenal hyperplasia, hypophosphatemia and ovarian cysts. ${ }^{5}$ Gonadotropin independent precocious puberty is the most common endocrinopathy which is more common in girls. Other endocrine and non-

e-ISSN 2308-118X

Printed in the Philippines

Copyright $(2015$ by the JAFES

Received March 7, 2015. Accepted May 4, 2015.

http://dx.doi.org/10.15605/jafes.030.01.05 endocrine organs like the heart, adrenal, thyroid, pituitary and liver can be involved. ${ }^{1,2}$

Rarely, manifestations of rickets and osteomalacia are present in children and adolescents diagnosed to have fibrous dysplasia. These patients have the characteristic biochemical profile of hypophosphatemia with phosphaturia, attributed to the hypersecretion of a phosphatonin fibroblast growth factor 23 (FGF23) from dysplastic bone lesions. , $^{1,2,4}$

We present a case of the classic triad of MAS along with hypophosphatemic rickets. Only a few cases have been reported with simultaneous involvement of precocious puberty and hypophosphatemic rickets along with fibrous dysplasia and café-au-lait macules.

\section{CASE}

A 31/2-year-old girl was admitted for evaluation of enlargement of both breasts along with vaginal bleeding for $2 \frac{1}{2}$ months. The girl was born of a non-consanguineous marriage, full-term, normal vaginal institutional delivery with cephalic presentation and cried immediately after birth. There were no feeding difficulties, no jaundice, no lactose intolerance and no developmental delay. There were no other chronic illnesses, no decreased appetite, galactorrhea, hypothyroidism, hypocortisolism, head

Corresponding author: Manish Gutch, $M D$

Department of Endocrinology

D-15 Lala Lajpat Rai Memorial Medical College

Meerut - 250004, Uttar Pradesh, India

Email: manish07gutch@gmail.com 
trauma, meningitis, seizures, encephalitis, visual field defect, brain surgery, radiation, defective smell, difficulty in vision, difficulty in walking or deformity of extremities. There was no significant maternal drug intake.

\section{Anthropometry}

The following is her anthropometric data: Height: $90 \mathrm{cms}$ (3-10 percentile), Arm Span: 88 cms, Mean Parental Height: $161.5 \mathrm{~cm}$, Weight: $15 \mathrm{~kg}$ (50-75 percentile).

\section{Physical Examination}

Her physical exam revealed a conscious, fully oriented female child, with feminine facies and body contour, antalgic gait, thyroid gland not enlarged, normal hair distribution, Marshall and Tanner stage: $A_{0} P_{1} B_{3}$, There was no hirsutism, nor clitoromegaly. Her pulse was 70/min, regular, with normal peripheral pulses; BP was 90/52 $\mathrm{mm} \mathrm{Hg}$, with no postural fall. Chest, cardiovascular, abdominal, and neurologic examinations were normal. There was tenderness over the left thigh with restriction in movement of the left hip joint. There were café-au-lait spots on the left side of the face. (Figure 1).

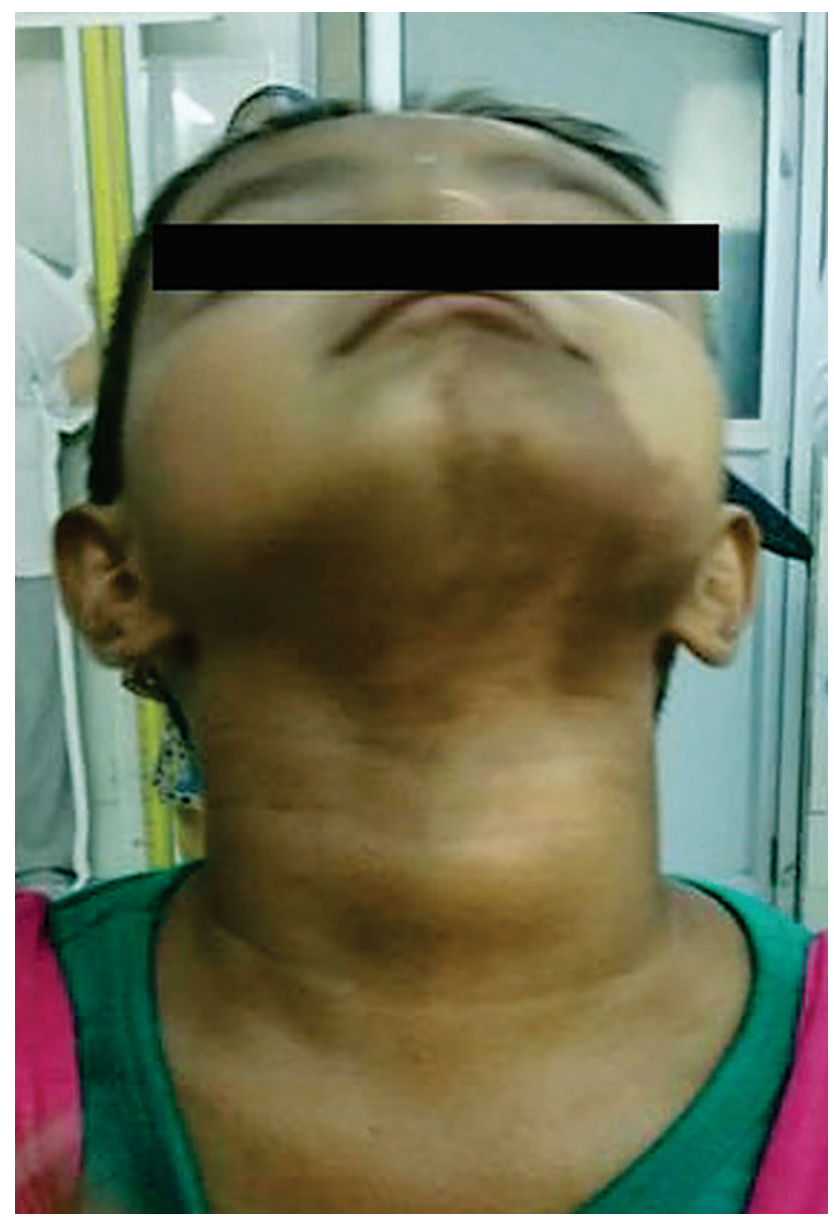

Figure 1. Café-au-lait spot involving left side of chin and upper neck.

\section{Laboratory Investigations}

Basal levels of luteinizing hormone ( $\mathrm{LH})$ and folliclestimulating hormone (FSH) were low (0.4 and $0.7 \mathrm{IU} / \mathrm{L}$, respectively), with no change in response to stimulation by $100 \mathrm{mg}$ of triptorelin (Table 1).

\begin{tabular}{|c|c|c|c|}
\hline S.No. & Parameter & $\begin{array}{l}\text { Observed } \\
\text { value }\end{array}$ & Normal Range \\
\hline 1 & Arterial $\mathrm{pH}$ & 7.394 & $7.35-7.45$ \\
\hline 2 & $\mathrm{Hb}$ & $10.7 \mathrm{gm} / \mathrm{dl}$ & $12.0-15.8 \mathrm{gm} / \mathrm{dl}$ \\
\hline 3 & TLC & $8200 / \mathrm{cmm}$ & $3.54-9.06 \times 10^{3} / \mathrm{mm}^{3}$ \\
\hline 4 & DLC & $\mathrm{P}_{50} \mathrm{~L}_{45}$ & $\mathrm{P}_{40-70} \mathrm{~L}_{20-50} \mathrm{M}_{4-8} \mathrm{E}_{0-6} \mathrm{~B}_{0-2}$ \\
\hline 5 & Platelet Count & $2.5 \mathrm{lac}$ & 1.65-4.15lac \\
\hline 6 & ESR & $10 \mathrm{~mm}$ Isthr & $0-20 \mathrm{~mm}$ Isthr \\
\hline 7 & $\begin{array}{l}\text { Blood Urea } \\
\text { Nitrogen }\end{array}$ & $14 \mathrm{mg} / \mathrm{dl}$ & $7-20 \mathrm{mg} / \mathrm{dl}$ \\
\hline 8 & S.creatinine & $0.40 \mathrm{mg} / \mathrm{dl}$ & $0.5-0.9 \mathrm{mg} / \mathrm{dl}$ \\
\hline 9 & SGOT & $23 \mathrm{U} / \mathrm{L}$ & $12-38 \mathrm{U} / \mathrm{L}$ \\
\hline 10 & SGPT & $36 \mathrm{U} / \mathrm{L}$ & $7-41 \mathrm{U} / \mathrm{L}$ \\
\hline 11 & ALP & $1184 \mathrm{IU} / \mathrm{L}$ & 44 to $147 \mathrm{IU} / \mathrm{L}$ \\
\hline 12 & Calcium & $9.4 \mathrm{mg} / \mathrm{dl}$ & $8.7-10.2 \mathrm{mg} / \mathrm{dl}$ \\
\hline 13 & Phosphorus & $2 \mathrm{mg} / \mathrm{dl}$ & $2.7-4.5 \mathrm{mg} / \mathrm{dl}$ \\
\hline 14 & Potassium & $4.1 \mathrm{meq} / \mathrm{L}$ & $3.5-5.0 \mathrm{meq} / \mathrm{l}$ \\
\hline 15 & TSH & $2.52 \mu \mathrm{lU} / \mathrm{ml}$ & $0.34-4.25 \mu \mathrm{lU} / \mathrm{ml}$ \\
\hline 16 & Estradiol $\left(\mathrm{E}_{2}\right)$ & $124.4 \mathrm{pg} / \mathrm{ml}$ & $<20 \mathrm{pg} / \mathrm{ml}$ \\
\hline 17 & $\begin{array}{l}\text { Luteinizing } \\
\text { hormone (LH) }\end{array}$ & $0.4 \mathrm{IU} / \mathrm{L}$ & $<2 \mathrm{IU} / \mathrm{L}$ \\
\hline 18 & $\begin{array}{l}\text { Follicle-stimulating } \\
\text { Hormone (FSH) }\end{array}$ & $0.7 \mathrm{IU} / \mathrm{L}$ & $<1 \mathrm{IU} / \mathrm{L}$ \\
\hline 19 & $25(\mathrm{OH}) \mathrm{D}$ & $42 \mathrm{nmol} / \mathrm{L}$ & $25-120 \mathrm{nmol} / \mathrm{L}$ \\
\hline 20 & Parathormone & $62 \mathrm{pg} / \mathrm{ml}$ & $11-54 \mathrm{pg} / \mathrm{ml}$ \\
\hline 21 & $\begin{array}{l}\text { Fibroblast growth } \\
\text { factor (FGF-23) }\end{array}$ & $254.3 \mathrm{pg} / \mathrm{mL}$ & 8.2 to $54.3 \mathrm{pg} / \mathrm{ml}$ \\
\hline
\end{tabular}

Pelvic ultrasound revealed left ovarian cysts measuring 3.70 and $3.4 \mathrm{~cm}$. The uterus was enlarged with a length of $4.6 \mathrm{~cm}$ (normal $\leq 3 \mathrm{~cm}$ ) and had a prominent endometrium.

X-ray of the lower limbs showed fibrous dysplasia involving the left femur (Figure 2) and skull x-ray showed ground glass appearance of the left orbit. (Figure 3).

Other investigations revealed normal serum calcium (9.4 $\mathrm{mg} / \mathrm{dL}$ ), phosphorus was reduced to $2 \mathrm{mg} / \mathrm{dL}$ (normal 2.7-4.5 mg/dL), markedly elevated serum alkaline phosphatase $1184 \mathrm{IU} / \mathrm{L}$ (normal 145-420 U/L), normal potassium $(4.1 \mathrm{meq} / \mathrm{L})$, normal $25(\mathrm{OH})$, D level of 42 $\mathrm{nmol} / \mathrm{L}(25-120 \mathrm{nmol} / \mathrm{L})$. Parathormone level was mildly elevated at $62 \mathrm{pg} / \mathrm{ml}$ (normal 11-54 pg/ml), fibroblast growth factor (FGF-23): $254.3 \mathrm{RU} / \mathrm{mL}$.

Arterial blood $\mathrm{pH}$ was 7.394 and urine $\mathrm{pH}$ was 5.3. Urine examination for glucose and amino acids was negative ruling out the possibility of proximal renal tubular acidosis.

After evaluation, she was diagnosed with McCuneAlbright syndrome with hypophosphatemic rickets, and was started on letrazole along with phosphate supplement and calcitriol. 


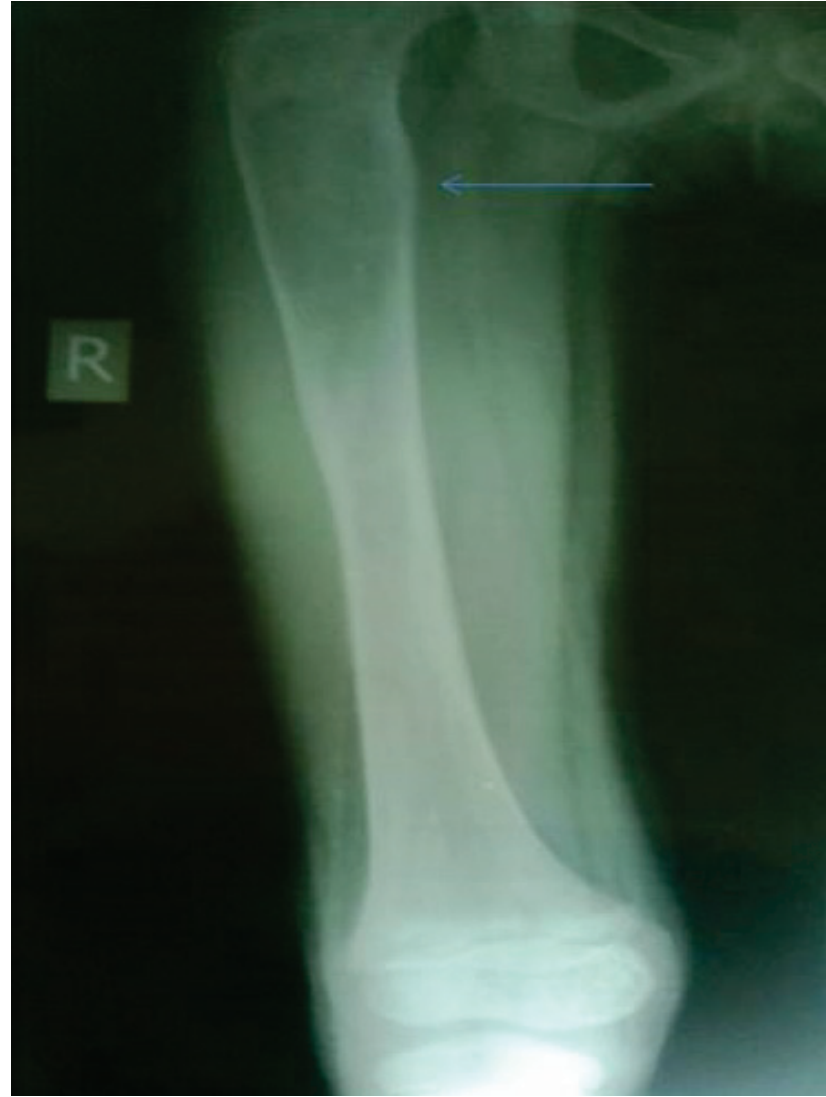

Figure 2. Well defined geographic lesions showing ground glass haze and sclerotic margins is seen involving left femoral metaphysics and diaphysis.

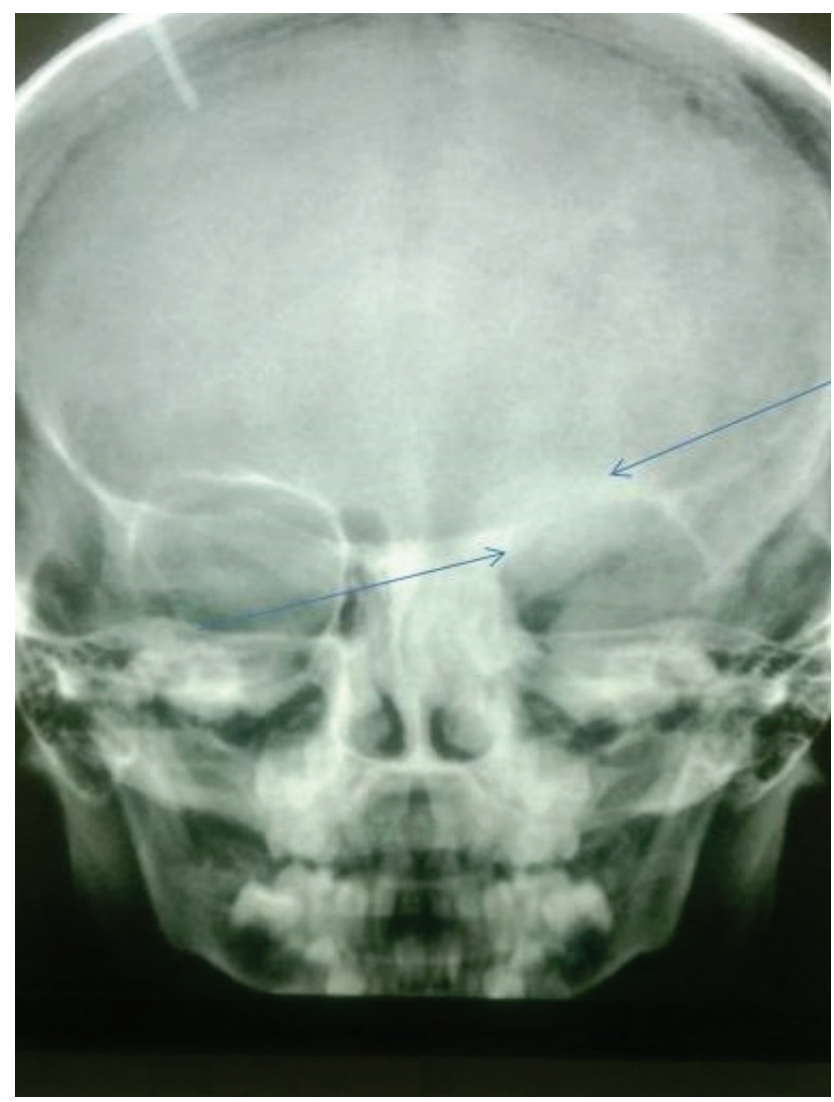

Figure 3. Lesions showing ground glass haze are seen involving roof, lateral and medial walls of left orbit.

\section{DISCUSSION}

McCune Albright Syndrome is a rare, multisystem disorder with female predilection, first described separately by Donovan McCune and Fuller Albright in 1937, in a group of children presenting with café-au-lait maculae, bone deformities and hyperfunctioning endocrinopathies attributed to an activating mutation of Gs gene. ${ }^{1}$ The syndrome is caused by a post-zygotic somatic mutation in GNAS1 gene located on 20q13-13.29, encoding for the alpha subunit of the stimulatory $G$ protein, resulting in the constitutive activity of the gene products. Normally, on binding of ligands to the receptor, the Gs $\alpha$ gets stimulated and dissociates from the receptor to activate adenylyl cyclase enzyme to increase the production of cAMP which mediates further signaling cascade. On inactivation, Gs $\alpha$ again reattaches with receptor for ligand mediated reactivation. ${ }^{1,2}$

The clinical presentation is heterogeneous with involvement of endocrine and non-endocrine organs depending on the number and the types of cells carrying the GNAS1 mutation. ${ }^{2}$ Similarly, the syndrome has varied evolution and progression. Usually the syndrome is diagnosed on the basis of the classic triad of fibrous dysplasia which develops due to the mutation in osteoprogenitor cells without differentiation, hyperfunctioning endocrinopathies along with isosexual precocious puberty and café-au-lait maculae mostly developing between the age of 4 months to 2 years but can be present at birth. 2,8

Fibrous dysplasia usually manifests during the first decade of life as aching pain, pathological fractures, limb asymmetry and deformities and is usually polyostotic, commonly involving the long bones, ribs and skull. Involvement varies greatly in severity from small, asymptomatic areas only detected on bone scan to highly disfiguring lesions leading to the pathological fractures and impingement of vital organs. ${ }^{7}$

Sometimes MAS is associated rarely with hypophosphatemic rickets, a group of disorders with the common denominator of defective renal phosphate reabsorption leading to phosphaturia and hypophosphatemia. The most common form is X-linked hypophosphatemic rickets. Acquired forms of hypophosphatemic rickets are associated with mesenchymal tumors, hemangiomas and soft-tissue tumors. ${ }^{1,2}$ Hypophosphatemic rickets associated with MAS is caused by the overproduction of the phosphatonin FGF23 by the cells in the dysplastic region of the bone.

McCune-Albright syndrome is considered a complex disease because of its varied manifestations and severity. No definite treatment and prenatal diagnosis is possible at present. A recent novel technique of PCR for activating mutation in the peripheral blood cells can help diagnose 
the disease. ${ }^{2,7,10}$ Depending on the number and extent of the endocrine and non-endocrine manifestations, various medical and surgical therapies can be offered. ${ }^{9}$

Among all the manifestations, the management of fibrous dysplasia is particularly difficult especially in children. Bisphosphonates like pamidronate, have a good short term safety profile and relieve pain, prevent fractures and partially resolve lesions. Sometimes corrective surgeries can be offered for fibrous dysplasia lesions. ${ }^{11}$

\section{CONCLUSION}

Precocious puberty can also be an early manifestation of McCune-Albright syndrome and the etiologic diagnosis of early sexual precocity is based on careful history and physical examination.

Children with precocious puberty should be evaluated for endocrinopathies and hormonal studies may be necessary in such cases.

\section{References}

1. Albright F, Butler AM, Hampton AO. Syndrome characterized by osteitis fibrosa disseminata, areas of pigmentation and endocrine dysfunction, with precocious puberty in females. N Engl J Med. 1937; 216(17):727-46. http://dx.doi.org/10.1056/NEJM193704292161701.

2. Lumbroso S, Paris F, Sultan C. Activating Gs $\alpha$ mutations: Analysis of 113 patients with signs of McCune-Albright syndrome - A European Collaborative Study. J Clin Endocrinol Metab. 2004; 89(5):2107-2113. http://dx.doi.org/10.1210/jc.2003-031225.
3. Chopra R, Chander A, Jacob JJ. The eye as a window to rare endocrine disorders. Indian J EndocrMetab. 2012;16(3):331-8. http://dx.doi.org/10.4103/2230-8210.95659.

4. Dumitrescu CE, Collins MT. McCune-Albright syndrome. Orphanet J Rare Dis. 2008; 19; 3:12. http://dx.doi.org/10.1186/1750-1172-3-12.

5. Xavier SP, Ribeiro MC, Sicchieri LG, Brentegani LG, Lacerda SA. Clinical, microscopic and imaging findings associated to McCuneAlbright syndrome: Report of two cases. Braz Dent J. 2008;19(2): 165-70.

6. Medow JE, Agrawal BM, Resnick DK. Polyostotic fibrous dysplasia of the cervical spine: Case report and review of the literature. Spine J. 2007;7(6):712-5. http://dx.doi/10.1016/j.spinee.2006.10.023.

7. DiCaprio MR, Enneking WF. Fibrous dysplasia.Pathophysiology, evaluation, and treatment. J Bone Joint Surg Am. 2005; 87(8):184864. http://dx.doi.org/10.2106/JBJS.D.02942

8. Papadopoulou M, Doula S, Kitsios K, Kaltsas T, Kosta K. A boy with McCune-Albright syndrome associated with GH secreting pituitary microadenoma. Clinical findings and response to treatment. Hormones (Athens). 2006;5(3):205-9. http://dx.doi.org/10.14310/horm. 2002.11186.

9. Bhadada SK, Bhansali A, Das S, Singh R, Sen R, Agarwal A, et al. Fibrous dysplasia and McCune-Albright syndrome: An experience from a tertiary care centre in north India. Indian J Med Res. 2011;133(5):504-9.

10. Lietman SA, Ding C, Levine MA. A highly sensitive polymerase chain reaction method detects activating mutations of the GNAS gene in peripheral blood cells in McCune-Albright syndrome or isolated fibrous dysplasia. J Bone Joint Surg Am. 2005; 87(11):248994. http://dx.doi.org/10.2106/JBJS.E.00160.

11. Lane JM, Khan SN, O'Connor WJ, Nydick M, Hommen JP, Schneider $\mathrm{R}$, et al. Bisphosphonate therapy in fibrous dysplasia. Clin Orthop Relat Res. 2001; 382:6-12.

Articles and any other material published in the JAFES represent the work of the author(s) and should not be construed to reflect the opinions of the Editors or the Publisher. Authors are required to accomplish, sign and submit scanned copies of the JAFES Declaration: that the article represents original material, that is not being considered for publication or has not been published or accepted for publication elsewhere. Consent forms, as appropriate, have been secured for the publication of information about patients; otherwise, authors declared that all means have been exhausted for securing such consent. The authors have signed disclosures that there are no financial or other relationships that might lead to a conflict of interest. All authors are required to submit Authorship Certifications that the manuscript has been read and approved by all authors, and that the requirements for authorship have been met by each author.

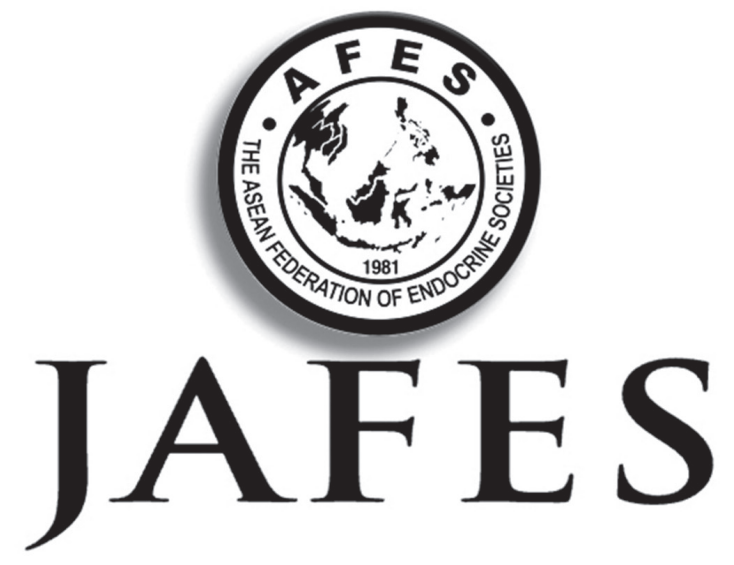

\section{Topics with cultural interest $=$ Images of Asia at JAFES @ Asia.com}

